Pediat. Res. 4: 318-327 (1970)

Anemia

growth

hypoproteinemia

malnutrition mental retardation

phenylalanine

phenylketonuria rickets

\title{
Malnutrition with Early Treatment of Phenylketonuria
}

\author{
W. B. Hanley ${ }^{[73]}$, Lydia Linsao, W.Davidson and C.A.F. Moes \\ The Hospital for Sick Children, and Departments of Pediatrics and Radiology, \\ University of Toronto, Toronto, Canada
}

\begin{abstract}
Extract
Thirty-two children with phenylketonuria in whom dietary therapy was started prior to 6 months of age are reviewed. Evidence of profound malnutrition during year 1 of life, demonstrated by deficient growth, anemia, hypoproteinemia, roentgenographic bone changes, and various clinical symptoms, was found in three patients. In two of these patients, the malnutrition was quickly corrected; present intelligence levels in these patients are dull normal. The third patient, however, suffered prolonged malnutrition and the present IQ is only 50 . Signs of less severe but prolonged malnutrition were found in 16 patients with phenylketonuria despite apparently adequate diets and adequate levels of phenylalanine in serum. Three of these are retarded, five are borderline, six are in the dull normal intelligence range, and two are normal.

In 13 recently diagnosed cases of phenylketonuria, more liberal amounts of phenylalanine and protein were given that resulted in moderate elevation of phenylalanine levels in serum. No evidence of malnutrition was found in these children and present IQ tests showed that none was testing retarded or borderline; four were rated as dull normal and nine were normal.
\end{abstract}

\section{Speculation}

The possibility is raised that mental retardation was produced by early malnutrition from too vigorous application of dietary therapy in phenylketonuria. It is suggested that more liberal diets would prevent this malnutrition and that despite moderate elevation of phenylalanine levels in serum, ultimate intellectual function will be improved.

\section{Introduction}

Many favorable reports have been published on the value of a low phenylalanine diet in the treatment of phenylketonuria (PKU) [2, 3, 8, 15, 20, 34, 38, 39, 41]. The enthusiasm of early workers has been tempered by more critical assessment of long-term results [5-7, $9,24,29,37]$.

Mass screening of newborns for phenylketonuria now results in most patients beginning dietary treatment during the first few weeks of life. Little attention has been paid to the hazards of feeding a synthetic low phenylalanine diet to young infants although at least seven deaths $[6,21,23,24,31,48,53]$ associated with, but not necessarily caused by, such diets have been reported. Various complications of dietary treatment have been described including peculiar roentgenographic bone changes $[8,25,26,44]$, vacuolization of 
red cell precursors in the bone marrow $[35,57]$, megaloblastic anemia [53], hypoglycemia [21, 23], hypoproteinemia [32], 'phenylalanine deficiency syndrome' $[11,52,63]$, poor weight gain $[43,63]$, cutaneous lesions [52, 63], and impaired antibody responses [62].

A number of authors admit that weight gain and linear growth of their treated patients has been retarded $[1,6,13,35,41,57]$, while others state that these indices have been maintained within the normal range $[7,8,32,61]$. Though it has been reported that untreated patients with phenylketonuria are small in stature $[27,36,45]$, no data have been presented to support this claim and others have even challenged this statement $[26,56]$.

Rouse [52] described two infants, erroneously fed a low phenylalanine diet on the basis of false positive screening tests, who later developed the 'phenylalanine deficiency syndrome'. They were subsequently found not to have phenylketonuria and were returned to a normal diet. Despite improvement in nutritional status, their intellectual progress has so far remained slow.

In 1963-1965, a number of reports suggested that malnutrition in the first 6 months of life resulted in permanent subnormal mentality despite correction of the malnutrition $[12,17,18,55,60]$. Malnutrition in older children, however, did not induce this permanent brain damage. We became concerned that these findings might apply to our young (under 6 months) infants receiving dietary treatment for PKU.

Evidence that malnutrition in the first 6 months of life may produce permanent subnormal mentality continues to accumulate $[67,68]$.

In late 1965 , we became dissatisfied with the progress of our patients who had received early treatment for phenylketonuria. Nearly all had poor weight gain and linear growth despite diets that maintained the phenylalanine levels in serum at concentrations considered adequate (table $\mathrm{I}$ ). The intelligence quotients were not as high as expected. Three patients developed profound malnutrition before 6 months of age. We wondered if our treatment was producing permanent mental retardation due to malnutrition caused by too vigorous restriction of phenylalanine and protein during the early months of life.

This paper presents data on 32 patients in whom dietary therapy was started prior to 6 months of age and who are now 2 years of age or over.

\section{Materials and Methods}

Dietary treatment of phenylketonuria was started in our clinic in 1958; at present we have in our care 89 patients, the 32 reported in this paper, 46 in whom dietary treatment was not started until after 6 months of age, and 11 who are at present too young (under 2 years) for adequate $D Q / I Q$ assessment. During the early stages of therapy, patients on diet therapy were seen in the clinic every 1 or 2 weeks. The interval was gradually extended to every 2 or 3 months in the older child, depending on their control and response to treatment.

Urine Phenistix [69] and Guthrie tests [28] using heel-prick blood, as well as determination of quantitative serum phenylalanine levels by the fluorometric method of MaCAMAN and RoBbins [42] were performed at each visit (before 1963 the method of UDENFRIEND and COOPER $[64,65]$ was used). For the past 18 months, parents have cooperated by collecting blood specimens for Guthrie tests twice weekly at home. In addition, levels of hemoglobin and serum proteins were determined and long bone roentgenograms, and other appropriate investigations were performed at various intervals. The parents and patients were interviewed by a nurse, a dietitian, a psychologist, and a pediatrician during each visit. Psychological tests used were the Cattell, the Stanford-Binet, and the Wechsler scales [70].

From 1958 to 1963 , the aim of our treatment was to maintain the fasting phenylalanine levels in serum within the normal range of 1-3 mg/100 ml; from 1963 to 1965 we allowed values up to $5 \mathrm{mg} / 100 \mathrm{ml}$. Early studies [46] had suggested that the intake of $25 \mathrm{mg}$ phenylalanine $/ \mathrm{kg} / 24 \mathrm{~h}$ provided by Lofenalac [71] alone would be sufficient to maintain these levels and at the same time allow for optimal growth, but we found that at least $50 \mathrm{mg}$ phenylalanine $/ \mathrm{kg} / 24 \mathrm{~h}$, obtained by adding small amounts of whole milk, were always necessary in young infants. Despite monitoring the phenylalanine levels in serum every 1-2 weeks in the early months, great difficulty was found in preventing intermittent low phenylalanine readings. Growth was not satisfactory.

Because of our observations in these early patients, we changed our treatment in late 1965 to allow fasting phenylalanine levels in serum between 5 and $15 \mathrm{mg} /$ $100 \mathrm{ml}$. Most concentrations are now between 8 and $12 \mathrm{mg} / 100 \mathrm{ml}$. This was achieved by providing $50-100$ $\mathrm{mg}$ phenylalanine $/ \mathrm{kg} / 24 \mathrm{~h}$ during year 1 of life.

\section{Results}

The 32 cases in this study can be considered conveniently in three groups (table I). Group 1, 3 infants who manifested profound malnutrition during the early treatment period; group 2, 16 infants, most of whom showed less severe but nevertheless definite and prolonged evidence of malnutrition; and group 3, 13 in- 


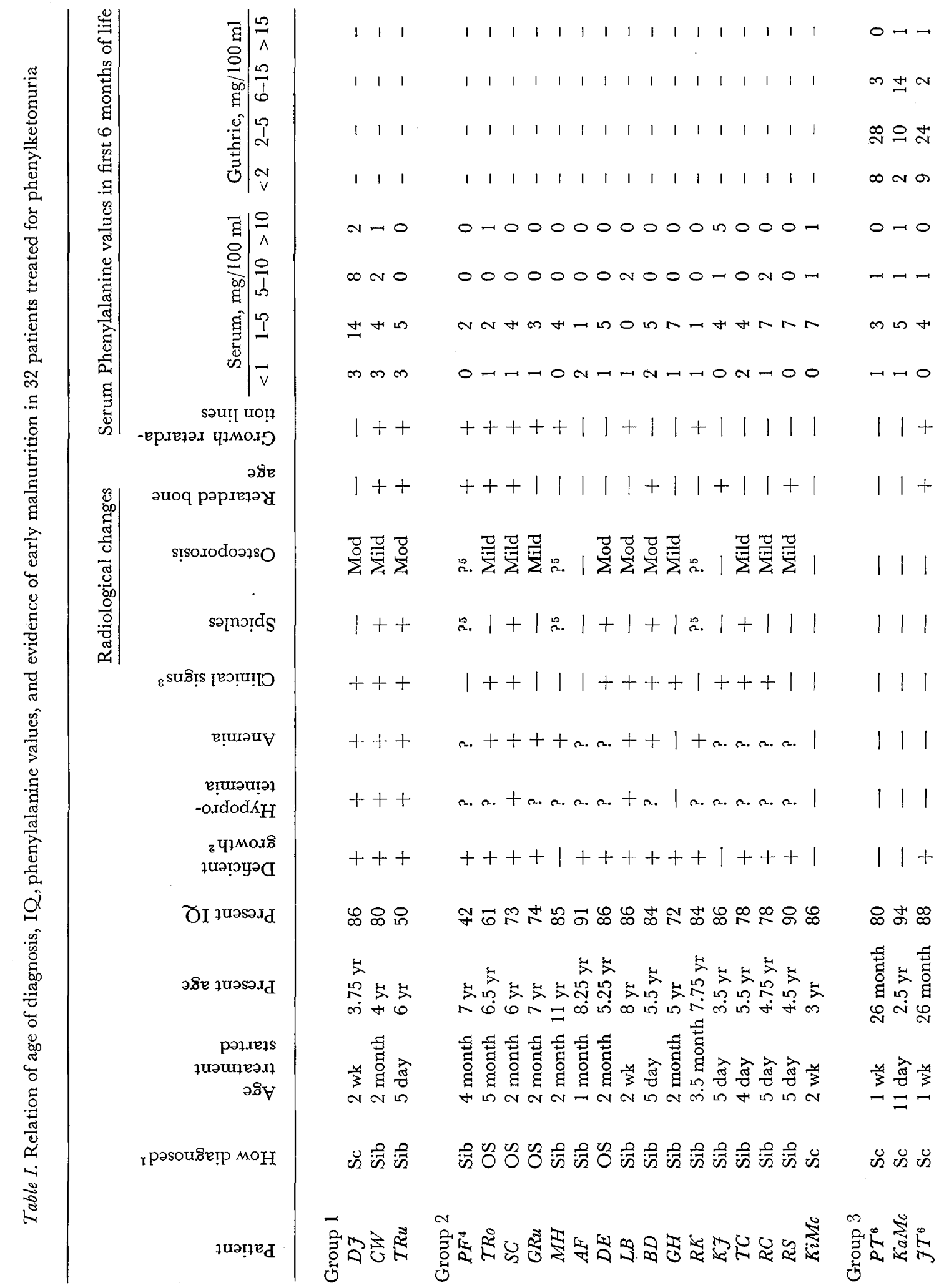




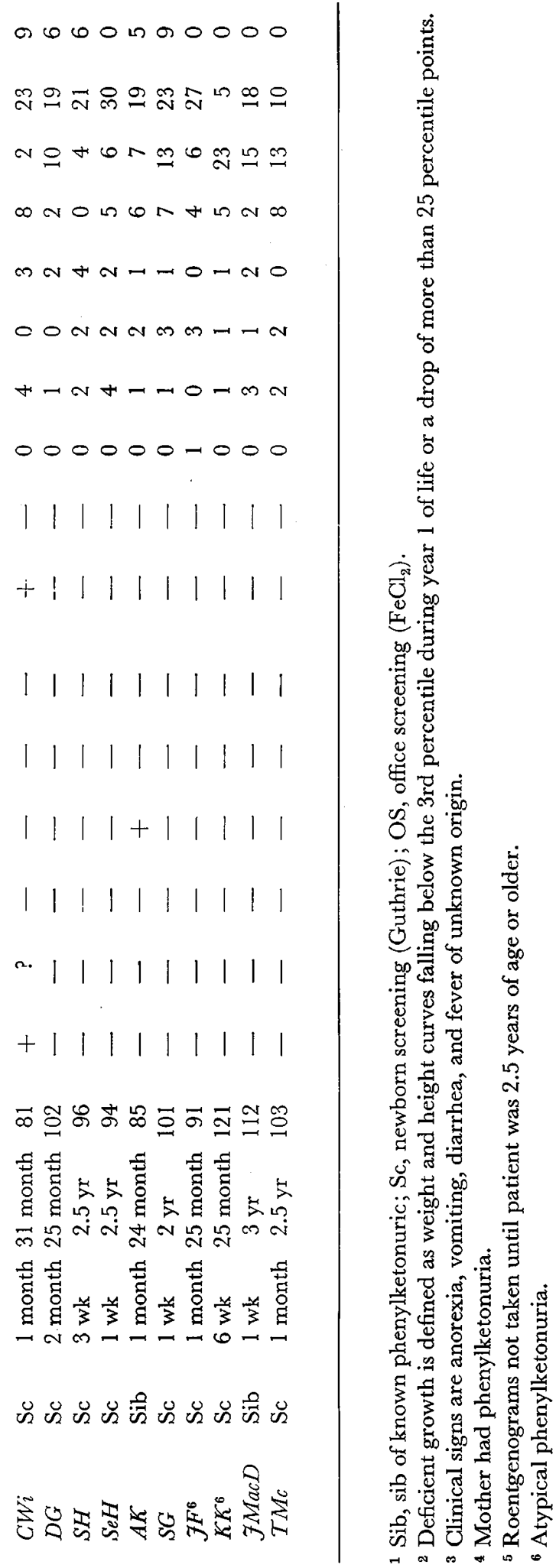

fants diagnosed within the past 3.5 years, who have been given more liberal allowances of phenylalanine and protein in their diets. In these we have found little evidence of malnutrition.

Group 1

Case no. 1 ( $D \mathcal{J})$. This infant had a positive Guthrie screening test at 4 days of age; at 2 weeks of age, the phenylalanine level in serum was $82 \mathrm{mg} / 100 \mathrm{ml}$. She was fed a diet of Lofenalac and whole milk to provide $50 \mathrm{mg}$ phenylalanine $/ \mathrm{kg} / 24 \mathrm{~h}$ and was discharged from the hospital at 1 month of age with a phenylalanine level of $9.6 \mathrm{mg} / 100 \mathrm{ml}$.

She was readmitted at 3 months of age with anorexia, vomiting, diarrhea, and poor weight gain (fig. 1). At this time she was receiving $35 \mathrm{mg}$ phenylalanine $/ \mathrm{kg} /$ $24 \mathrm{~h}$. This was gradually increased to $60 \mathrm{mg} / \mathrm{kg} / 24 \mathrm{~h}$. She became dehydrated and was in a state of electroIyte imbalance. Protein levels in serum fell to $3.72 \mathrm{~g} /$ $100 \mathrm{ml}$ (albumin $1.14 \mathrm{~g} / 100 \mathrm{ml}$, globulin $2.58 \mathrm{~g} / 100 \mathrm{ml}$ ) and her hemoglobin level dropped to $9.5 \mathrm{~g} / 100 \mathrm{ml}$ despite supplemental iron. Long bone roentgenograms revealed osteoporosis, metaphyseal cupping with spicules, and marginal beaking. Her condition continued to deteriorate and at 4 months of age she was fed whole milk for a 2-week period. During this time phenylalanine concentration rose to $30 \mathrm{mg} / 100 \mathrm{ml}$, all clinical symptoms disappeared, and serum electrolyte, proteins, and hemoglobin levels gradually returned to normal.

Fig. 1. Weight curves of patients in group 1 (note that only patient $T R u$ had evidence of prolonged malnutrition).

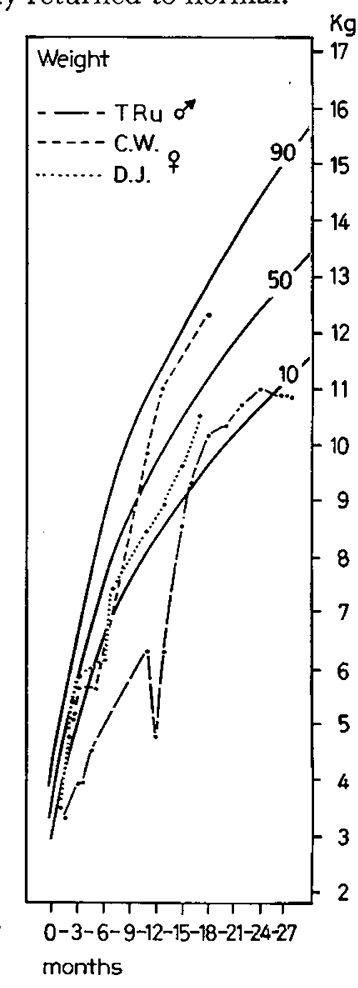


At the end of this period; a low phenylalanine diet was reinstituted providing $100 \mathrm{mg}$ phenylalanine $/ \mathrm{kg} /$ $24 \mathrm{~h}$. She has remained well and maintains phenylalanine concentrations in serum from 5 to $10 \mathrm{mg} / 100$ $\mathrm{ml}$. Her most recent IQ, at 3 years of age, was 86 .

Case no. 2 (TRu). This patient, the sibling of a child with phenylketonuria, had phenylalanine levels in serum of 18 and $36 \mathrm{mg} / 100 \mathrm{ml}$ on days 4 and 5 of life. $\mathrm{He}$ was fed a diet containing $25 \mathrm{mg}$ phenylalanine $/ \mathrm{kg} /$ $24 \mathrm{~h}$ and 4 weeks later the phenylalanine was increased to $50 \mathrm{mg} / \mathrm{kg} / 24 \mathrm{~h}$. Despite this increase he did poorly. During the first 8 months of his life he suffered from recurrent febrile episodes and required hospitalization three times. At 6 months of age he was admitted with vomiting, diarrhea, lethargy, skin rash, anorexia, and edema. Protein levels in serum were $3.82 \mathrm{~g} / 100 \mathrm{ml}$ (albumin $1.49 \mathrm{~g} / 100 \mathrm{ml}$, globulin $2.33 \mathrm{~g} / 100 \mathrm{ml}$ ) and the hemoglobin level was $7.8 \mathrm{~g} / 100 \mathrm{ml}$. Roentgenograms of hands, wrists, and knees showed mild osteoporosis, cupping and lipping, and metaphyseal spicule formation in the radius and ulna (fig. 2). When fed a diet containing $75 \mathrm{mg}$ phenylalanine $/ \mathrm{kg} / 24 \mathrm{~h}$ he gradually improved. His most recent IQ, at 6 years of age, was 50 . The home situation was poor in this family and may well have been an additional contributing factor to his poor development.

Case no. $3(\mathrm{CW})$. Phenylketonuria was detected at 2 months of age and she was fed a diet providing $40 \mathrm{mg}$ phenylalanine $/ \mathrm{kg} / 24 \mathrm{~h}$. Her growth and development appeared satisfactory until 6 months of age when she suddenly developed a rash, edema, and failed to gain weight. Levels of protein in serum were $3.8 \mathrm{~g} / 100 \mathrm{ml}$ (albumin $1.5 \mathrm{~g} / 100 \mathrm{ml}$, globulin $2.3 \mathrm{~g} / 100 \mathrm{ml}$ ) and phenylalanine concentrations ranged from 1 to $1.8 \mathrm{mg} /$ $100 \mathrm{ml}$. She had hypochromic anemia with a hemoglobin of $6.5 \mathrm{~g} / 100 \mathrm{ml}$. Roentgenograms revealed
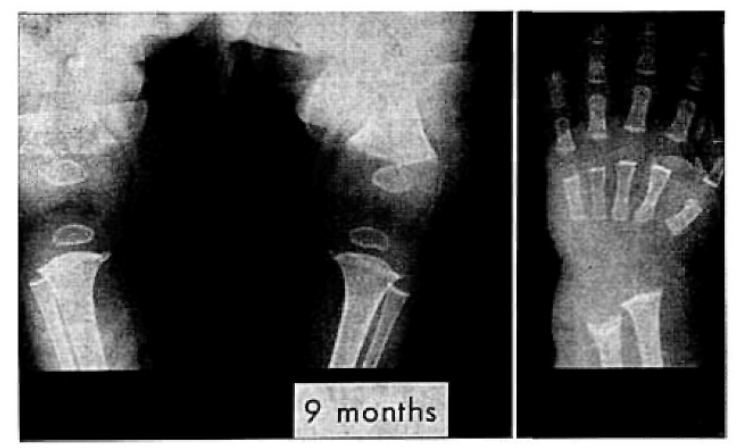

Fig. 2. Hand and knee roentgenograms of patient $\mathcal{T} R u$ (group 1) showing mild osteoporosis, cupping of the ulna and fibula, and marginal spur formation. Metaphyseal spicules are noted at the ends of the radius and ulna. diffuse osteoporosis of radius and ulna with typical spicular changes. The dietary phenylalanine was increased to $75 \mathrm{mg}$ and later to $100 \mathrm{mg} / \mathrm{kg} / 24 \mathrm{~h}$ and at the end of 2 weeks the level of proteins in serum had risen to $5.2 \mathrm{~g} / 100 \mathrm{ml}$ and hemoglobin to $8.2 \mathrm{~g} / 100 \mathrm{ml}$. She improved gradually and her most recent IQ, at 4 years of age, was 80 .

\section{Group 2}

These infants showed less profound but definite evidence of malnutrition; therefore, alerted by our experience with the infants of group 1, we looked, retrospectively, in 1965, at the remainder of our children with phenylketonuria in whom treatment was started early in life. Group 2 comprises the remaining 16 infants treated prior to 6 months of age up to late 1965 .

Evidence of malnutrition in early infancy in these 16 patients was revealed by the following (table I): 1) Growth retardation (defined here as weight and height curves dropping below the 3rd percentile in year 1 of life, or a drop of 25 or more percentile points during this period), exhibited by 13 of 16 patients in this group (fig. 3). 2) Episodes of vomiting, diarrhea [10], anorexia, and unexplained fever found in 9 of the 16 children. 3) Hypoproteinemia, in two of four patients studied. 4) Seven of nine tested had refractory anemia. 5) Fasting blood sugars were measured in four

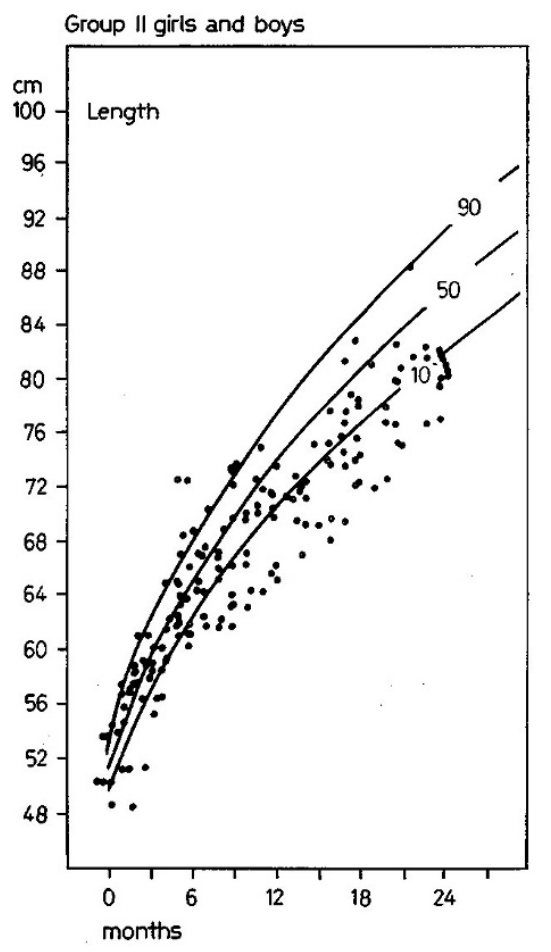

Fig. 3. Linear growth chart of patients in group 2. 
infants on six occasions; all were normal. Extensive investigations neither of levels of serum proteins and amino acids nor of bone marrow were performed. 6) The most striking and consistent findings aside from growth failure were the roentgenographic changes (fig.4). In three children no roentgenograms were made until they were 2.5 years of age or older. At this time, X-ray films showed only lines of growth retardation in two, and retarded bone age in one. Of the remaining 13 patients, a) 4 had metaphyseal spicules $[25,26], b) 10$ had osteoporosis, c) 4 had retarded bone age, d) 4 had lines of growth retardation, and e) X-ray films made at the time of diagnosis (i.e., before treatment) in 12 children were normal. In short, all but three of group 2 had roentgenographic evidence of osteoporosis with or without other bony changes during year 1 of life. Review of all phenylalanine determinations in serum during year 1 of life showed that $14 \%$ were less than $1 \mathrm{mg} / 100 \mathrm{ml} ; 66 \%$ were between 1 and $4 \mathrm{mg} / 100 \mathrm{ml}$; and $20 \%$ were over $4 \mathrm{mg} / 100 \mathrm{ml}$ (also see table I).

When these moderately malnourished infants became older the problems of anemia, diarrhea, and vomiting resolved without special treatment and the roentgenographic changes gradually disappeared. Weight gain and linear growth improved, so that by 2 years of age most had reached at least the lower range of normal for age. Phenylalanine requirements changed at age $18-24$ months to $25-30 \mathrm{mg} / \mathrm{kg} / 24 \mathrm{~h}$.

At present, the 16 patients of group 2 are 3-11 years old and recent IQ testing has shown 2 to be in the normal range, 6 dull normal, 5 borderline and 3 retarded (table II). The diagnosis of phenylketonuria was delayed in two ( $P F$ and $T R o$ ) of the three retarded children. One child $(P F)$, in whom the condition was not diagnosed until 4 months of age, now has an IQ of 40. He may have suffered intrauterine brain damage as his mother is a homozygous phenylketonuric.
Group 3

As a result of the findings in groups 1 and 2, we changed our treatment in late 1965 to allow fasting phenylalanine levels in serum to be maintained between 5 and $15 \mathrm{mg} / 100 \mathrm{ml}$. This required the provision of 50-100 mg phenylalanine $/ \mathrm{kg} / 24 \mathrm{~h}$ during year 1 of life.

With this more liberal diet, 2 of the 13 patients in group 3 have shown roentgenographic changes but none have had hypoproteinemia or anemia. Two have had brief episodes of deficient growth and one has had episodes of diarrhea and anorexia quickly corrected by dietary adjustments (usually made by adding more whole milk to the formula preparation).

Intelligence quotient testing of patients in group 3, at age 25-36 months, show nine normal, four dull normal, no borderline, and no retarded children (table II).

The improved results in these patients must be interpreted with caution for several reasons. The IQ of the patients in group 3, still only 25-36 months of
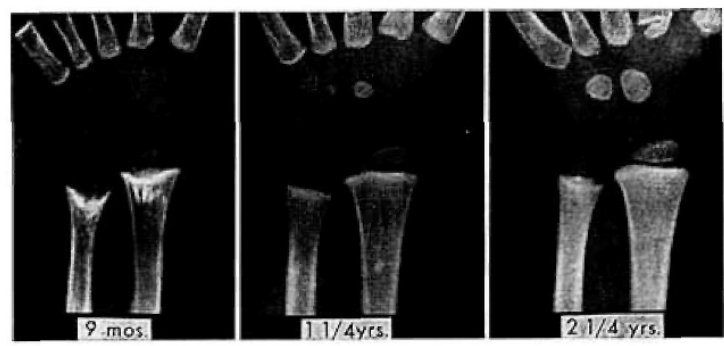

Fig. 4. Serial wrist roentgenograms of patient $D E$ (group 2) showing osteoporosis, metaphyseal spicules, and cupping. Irregular linear densities in the metaphysis are present. All conditions improving with age.

Table II. Analysis of present IQ levels of infants fed the more restricted diets (groups 1 and 2) compared with those fed the more liberal diet (group 3)

\begin{tabular}{|c|c|c|c|c|c|}
\hline \multirow[t]{2}{*}{ IQ } & & \multicolumn{2}{|c|}{ Groups 1 and 2 (all classical PKU) } & \multicolumn{2}{|c|}{ Group 3} \\
\hline & & $\begin{array}{l}\text { Diagnosed } \\
\text { before } 2 \text { months } \\
\text { of age }\end{array}$ & $\begin{array}{c}\text { Diagnosed } \\
\text { after } 2 \text { months } \\
\text { of age }\end{array}$ & Classic PKU & Atypical PKU \\
\hline Normal, $90+$ & - & 2 & 0 & 6 & 3 \\
\hline Dull normal, 80-89 & & 8 & 1 & 2 & 2 \\
\hline Borderline, 70-79 & & 5 & 0 & 0 & 0 \\
\hline Retarded, $<70$ & & 1 & 2 & 0 & 0 \\
\hline & & \multicolumn{2}{|c|}{19} & \multicolumn{2}{|c|}{13} \\
\hline
\end{tabular}




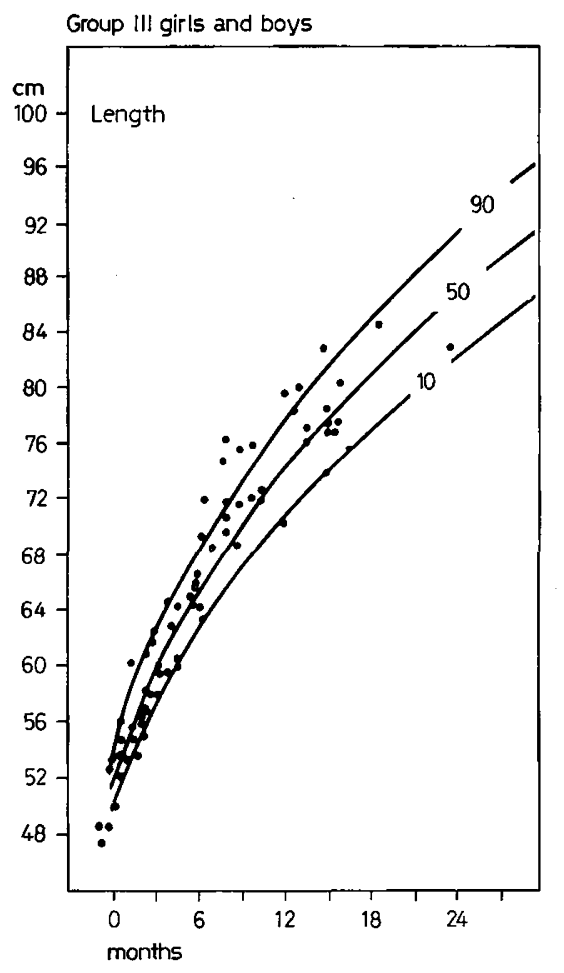

Fig.5. Linear growth chart of patients in group 3.

age, may not be predictably valid. The average age of diagnosis of the patients in group 3 was less than those in groups 1 and 2, and 5 of the 13 infants in group 3 are mild (atypical) phenylketonurics needing only moderate dietary restriction. Indeed two of them, 25 and 33 months of age, respectively, are now fed an unrestricted diet, and have blood phenylalanine levels ranging from 8 to $18 \mathrm{mg} / 100 \mathrm{ml}$. These five mild 'atypical' patients, however, do not fulfill the present criteria for atypical PKU (i.e., initial phenylalanine values in serum of never over $20 \mathrm{mg} / 100 \mathrm{ml}$ [32]) as their initial levels were all over $30 \mathrm{mg} / 100 \mathrm{ml}$ (31.8$38.5 \mathrm{mg} / 100 \mathrm{ml})$.

\section{Discussion}

Of the three children showing major manifestations of malnutrition, two suffered only for relatively brief periods and malnutrition was quickly corrected. The subsequent progress of these two has been fairly satisfactory. Their intelligence so far is in the low normal range. The third patient in group $1, T R u$, had a more prolonged and recurring problem (fig. 1) with malnutrition and at present has an IQ of 50 , at 6 years of age. His sibling, in whom the diagnosis was made at 2 months of age, has an IQ of 74 at 7 years of age. Two similar cases have been described in the literature $[4$, 57].

The 16 infants in group 2, though less seriously affected, usually had evidences of prolonged nutritional deprivation shown chiefly in their growth charts and roentgenograms (figs. 2 and 3).

Holt and Allen [30], in a study of 32 children who were treated for phenylketonuria, noted osteoporosis in one-half and retarded skeletal maturation in onethird. Twelve of their cases under 3 years of age had bony spicules, nine of these patients were under 1 year of age.

That malnutrition in early infancy causes permanent intellectual deficiency $[12,17,18,55,60]$ is so far only speculation. We cannot prove that the malnourished state produced in the young infants we fed phenylalanine-restricted diets has been harmful. A false diagnosis of phenylketonuria in a number of infants led to their being fed low phenylalanine diets for periods of 12-24 months [4, 11, 16, 52, 54]. Mental development in some of these children has been retarded. It is possible that this is due to ia trogenic malnutrition in the early months of life.

Experimental work has shown that poor myelinization, one of the pathological findings resulting from malnutrition, can be produced by subjecting animals to minimal degrees of malnutrition during the period of maximum myelinization [19]. Also, nutritional deprivation during the early life of a rat is associated with a decreased synthesis of sulfatide (a component of myelin) and this decreased synthesis is not corrected by refeeding [14].

Bessman [6] has pointed out that a much larger number of untreated phenylketonurics than originally estimated may have normal intelligence. Since severe degrees of malnutrition in infancy may cause permanent intellectual deficit, care should be exercised in controlling the phenylalanine levels in serum to avoid producing malnutrition lest the treatment be as damaging as the disease.

During the early history of dietary therapy, some authors [46] suggested that $25 \mathrm{mg}$ phenylalanine $/ \mathrm{kg} /$ $24 \mathrm{~h}$ were sufficient to maintain normal blood levels and also normal growth in young infants with phenylketonuria. This has proved fallacious and most workers now recommend an intake of at least $50 \mathrm{mg} / \mathrm{kg} / 24 \mathrm{~h}$ in the early months of life. Our experience indicates that even this figure is often too low and that 50-100 $\mathrm{mg} / \mathrm{kg} / 24 \mathrm{~h}$ (and occasionally $125 \mathrm{mg}$ ) is necessary. These figures are similar to the minimal phenylalanine requirements for normal growth in nonphenylketonuric infants which were shown by SNYDERMAn and Holt [58] to be $47-90 \mathrm{mg} / \mathrm{kg} / 24 \mathrm{~h}$. The average nor- 
mal 5-kg infant actually receives about $300-350 \mathrm{mg}$ phenylalanine $/ \mathrm{kg} / 24 \mathrm{~h}$ in the usual cows milk formula with added cereal and strained foods.

Infants fed on a wholly synthetic diet do not grow and thrive [58]. Gell growth is inhibited if the diet is low in any single essential amino acid [22]. Since whole milk must always be added to a Lofenalac diet during the first 6-12 months of life to maintain a good nutritional state, it is possible that this product is deficient in some yet undetermined nutrient.

There is some indirect evidence that levels of serum phenylalanine of up to $10-15 \mathrm{mg} / 100 \mathrm{ml}$ may not be harmful to young infants. As yet, mental retardation in children with untreated transient hyperphenylalaninemia has not been reported. Gross disruption of related amino acids and metabolites does not occur until the phenylalanine levels in serum are over 12-15 $\mathrm{mg} / 100 \mathrm{ml}$. Many of the untreated phenylketonurics with a high IQ have relatively low phenylalanine levels [33] and a number of these individuals have given birth to normal children.

For these reasons we have permitted phenylalanine levels in serum to reach $10-15 \mathrm{mg} / 100 \mathrm{ml}$ without being concerned. Perhaps as PARtington [49] suggests, the virtue of a low phenylalanine diet in the treatment of phenylketonuria lies not so much in maintaining normal levels of phenylalanine in the blood but in avoiding gross elevations.

In our 32 patients with phenylketonuria, diagnosed and treated prior to 6 months of age, we were unable, with the therapeutic diet used, to maintain the fasting phenylalanine levels at, or slightly above, the normal range and at the same time avoid definite clinical, laboratory, and radiological signs of malnutrition during year 1 of life. It is possible that permanent intellectual impairment was produced as a result of this malnutrition. We suggest that malnutrition can be avoided by allowing more liberal amounts of protein and phenylalanine in the diet and that the resulting moderate elevations of phenylalanine produced no impairment of intellect. We also suggest that it is most important to monitor the phenylalanine levels in serum once or twice weekly during the first 6-12 months of life, and also to watch for evidence of malnutrition in roentgenograms, serum protein levels, hemoglobin values, and growth and height gains.

More refined techniques for the evaluation of nutrition, such as measurements of hydroxyprolines in urine [66] and growth hormone studies [50], might also be of value in assessing the efficacy of the dietary treatment of this condition.
Summary

Studies of 32 patients with phenylketonuria, in whom dietary treatment was started before 6 months of age, are reported.

Evidence of profound malnutrition during year 1 of life was found in 3 cases, and less severe but prolonged malnutrition was found in most of the patients from a group of 16 despite phenylalanine levels in serum that were within the normal ranges.

In 13 cases that were recently diagnosed, more liberal amounts of phenlyalanine and protein were given that resulted in moderate elevations of phenylalanine levels. No evidence of malnutrition was found in these children, and their present IQ test scores are higher than those of the children who were fed the more restricted diets.

The possibility is raised that mental retardation was produced by early malnutrition from too vigorous application of dietary therapy.

\section{References and Notes}

1. Allen, R.J. and Wilson, J.L.: Urinary phenylpyruvic acid in phenylketonuria. J.amer.med. Ass. 188: 720 (1964).

2. Berman, P.W.; Waisman, H.A. and Graham, F.K.: Intelligence in treated phenylketonuric children: A developmental study. Ghild. Develop. 37: 731 (1966).

3. Berman, P.W.; Waisman, H.A. and Graham, F.K. : Effectiveness of dietary treatment in phenylketonuria: What is the proof? Develop. med. Ghild. Neurol. 9: 411 (1967).

4. Berry, H. K.; Sutherland, B.S. and Umbarger, B.: Diagnosis and treatment: Interpretation of results of blood screening studies for detection of phenylketonuria. Pediatrics 37: 102 (1966).

5. BERRY, H.K. and Wright, S.: Conference on treatment of phenylketonuria. J.Pediat. 70: 142 (1967).

6. Bessman, S. P. : Editorial. Legislation and advances in medical knowledge-acceleration or inhibition? J. Pediat. 69: 334 (1966).

7. Bessman, S.P.: (Guest Editorial). PKU-Some skepticism. New Engl.J.Med. 278: 1176 (1968).

8. Bickel, H. and Grüter, W.: Management of phenylketonuria. The intellectual response; in: E.L.Lyman: Phenylketonuria, pp. 145-167 (Thomas, Springfield, IL 1963).

9. Birch, H.G. and TIZARD, J.: The dietary treatment of phenylketonuria: not proven? Develop. med. Child. Neurol. 9: 9 (1967).

10. Bowie, M. D. ; Brinkman, G. L. and Hansen, J. D.: 
Diarrhoea in protein-calorie malnutrition. Lancet ii: 550 (1963).

11. Brimblecombe, F.S.W.; Blainey, J.D.; StoneMAN, M.E. and WooD, B.S.: Dietary and biochemical control of phenylketonuria. Brit.med.J. ii: 793 (1961).

12. Gabak, V. and Najdanvic, R.: Effect of undernutrition in early life on physical and mental development. Arch. Dis. Childh. 40: 532 (1965).

13. Genterwall, W.R.; Genterwall, S. A.; Armon, V. and MANn, L. B.: Phenylketonuria. II. Results of treatment of infants and young children. J. Pediat. 59: 102 (1961).

14. Ghase, H.P.; Dorsey, J. and Mckhaun, G.M.: The effect of malnutrition on the synthesis of a myelin lipid. Pediatrics 40: 551 (1967).

15. Glayton, B. ; Moncrieff, A. and Roberts, G. E. : Dietetic treatment of phenylketonuria: A follow-up study. Brit.med.J. iii: 133 (1967).

16. Cochrane, W.A.: Personal communication.

17. Cravioto, J.: Application of newer knowledge of nutrition on physical and mental growth and development. Amer.J.publ. Hlth. 53: 1803 (1963).

18. Cravioto, J.; De Licardie, E.R. and Birch, H.G. : Nutrition, growth and neurointegrative development: an experimental and ecologic study. Pediatrics 38: 319 (1966).

19. Dobbing, J.: The effect of undernutrition on myelination in the C.N.S. Biol:Neonat. 9: 132 (196566).

20. Dobson, J.; КоGh, R.; Williamson, M.; Spector, R.; FrankenberG, W.; O'FlynN, M.; Warner, R. and Hudson, F.: Cognitive development and dietary therapy in phenylketonuric children. New Engl.J. Med. 278: 1142 (1968).

21. Dodge, P.R.; Mangall, E.L.; Crawford, J.D.; Knapp, J. and Paine, R.S.: Hypoglycemia complicating treatment of phenylketonuria with a phenylalanine-deficient diet. New Engl.J.Med. 260: 1104 (1959).

22. EAgle, H.; Piez, K. A. and Levy, M.: The intracellular amino acid concentrations required for protein synthesis in cultured human cells. J. biol. Chem. 236 : 2039 (1961).

23. FArber, S. and VAwTER, G.F.: Glinical pathological conference. J. Pediat. 63: 667 (1963).

24. FARQuhar, J.W.; RIchmond, J. and TAIT, H.P.: Phenylketonuria in paediatric practice-A review. Clin.pediat. 2: 504 (1963).

25. Feinberg, S. B. and Fisch, R.O.: Roentgenologic findings in growing long bones in phenylketonuria. Radiology 78: 394 (1962).

26. Fisch, R.O.; Gravem, H.J. and Feinberg, S. B.: Growth and bone characteristics of phenylketonurics. Comparative analysis of treated and un- treated phenylketonuric children. Amer.J. Dis. Child. 112: 3 (1966).

27. Grumer, H.D.: Synopsis of some current studies in phenylketonuria. J.Maine med.Ass. 53: 8 (1962).

28. GuThrie, R. : Blood screening for phenylketonuria. J.amer.med. Ass. 178: 863 (1961)

29. Hackney, I. M.; Hanley, W.B.; Davidson, W. and Linsao, L.: Phenylketonuria. I. Mental development, behaviour and termination of low phenylalanine diet. J. Pediat. 72: 646 (1968).

30. Holt, J.F. and Allen, R.J.: Radiologic signs in the primary aminoacidurias. Ann. Radiol., Paris 10: 317 (1967).

31. Holt, K.S.: Difficulties and dangers in the management of phenylketonuria. Acta paediat. scand. 52: 417 (1963).

32. Hsia, D.Y.-Y.: Phenylketonuria : A study of human biochemical genetics. Pediatrics 38: 173 (1966).

33. Hsia, D.Y.-Y.; O'Flynn, M.E. and Berman, J. L. : Atypical phenylketonuria with borderline or normal intelligence. Amer.J. Dis. Child. 116: 143 (1968).

34. Hudson, F.P.; Dickinson, R.A. and Ireland, J.T.: Experiences in the detection and treatment of phenylketonuria. Pediatrics 31: 47 (1963).

35. Ingall, D.; Sherman, J.D.; Cockburn, F. and KLEIN, R.: Immediate effects of phenylalaninedeficient diet in young infants (Abstracts). Society for Pediatric Research, 34th Annual Meeting, Seattle, Washington, June 1964. J. Pediat. 65: 1073 (1964).

36. Jervis, G.A.: The clinical picture; in: E.L.LyMAN : Phenylketonuria, pp.52-61 (Thomas, Springfield, IL 1963).

37. Kleinman, D.S.: Phenylketonuria: A review of some deficits in our information. Pediatrics 33: 123 (1964).

38. KNox, W.E.: An evaluation of the treatment of phenylketonuria with diets low in phenylalanine. Pediatrics 26: 1 (1960).

39. Косн, R.; Cecerta, P. and Fischler, K.: Observations of phenylketonuria; in: J.A. Anderson: Phenylketonuria and allied metabolic diseases. Proc. of a Conference, Washington, DG, April 1966 (U.S. Government Printing Office).

40. LEwIS, I. C.: An unusual case of phenylketonuria. Med.J. Austr. II: 811 (1960).

41. MaBean, M.S. and Stephenson, J.B.P.: Treatment of classical phenylketonuria. Arch. Dis. Ghilh. 43: 1 (1968).

42. MaCaman, M.W. and Robrins, E.: Fluorimetric method for the determination of phenylalanine in serum. J.Lab. clin. Med. 59: 885 (1962).

43. Moncrieff, A. and Wilkinson, R.H.: Further 
experiences in the treatment of phenylketonuria. Brit.med.J. $i$ : 763 (1961).

44. Murdock, M.M. and Holman, G.H.: Roentgenologic bone changes in phenylketonuria-relation to dietary phenylalanine and serum alkaline phosphatase. Amer. J. dis. Child. 107: 523 (1964).

45. Paine, R.S.: Phenylketonuria. Clin. Proc. Hosp. Wash. 20: 143 (1964).

46. Paine, R.S. and Hsia, D.Y.-Y.: The dietary phenylalanine requirements and tolerances of phenylketonuric patients. Amer. J. Dis. Child. 94: 224 (1957).

47. Partington, M.W.: Observations on phenylketonuria in Ontario. Canad.med.Ass.J. 84: 985 (1961).

48. Partington, M.W. and Anderson, R.M.: Casefinding in phenylketonuria. I. Report of a survey by the College of General Practice of Canada. Canad.med. Ass. J. 90: 1312 (1964).

49. Partington, M.W. and Lewis, E.J.: Variations with age in plasma phenylalanine and tyrosine levels in phenylketonuria. J. Pediat. 62: 348 (1963).

50. Pimstone, B.; Barbezat, G.; Hansen, J. D. L. and Murray, P.: Growth hormone and proteincalorie malnutrition. Impaired suppression during induced hyperglycaemia. Lancet $i i$ : 1333 (1967).

51. Prtт, D. and Wilmor, A.E.: Phenylketonuria in Victoria. Med.J. Austr. I: 33 (1965).

52. Rouse, B. M. : Phenylalanine deficiency syndrome. J.Pediat. 69: 246 (1966).

53. Royston, N.J.W. and PARry, T.E.: Megaloblastic anaemia complicating dietary treatment of phenylketonuria in infancy. Arch. Dis. Childh. 37: 430 (1962).

54. Schneider, A.J. and Garrard, S.D.: Persistent hyperphenylalaninemia (Abstract). American Pediatric Society, 75th Annual Meeting, Philadelphia, May 1965.

55. ScRImshaw, N.S. and BÉhar, M.: Malnutrition in underdeveloped countries. New Engl.J.Med. 272: 137 (1965).

56. SHAw, K.N.F.: Biochemical aspects of phenylketonuria; in: The clinical team looks at phenylketonuria. Children's Bureau, U.S. Dept. of Health, Education and Welfare 1964 (U.S. Government Printing Office).

57. Sherman, J.D.; Greenfield, J.B. and Ingall, D.: Reversible bone-marrow vacuolizations in phenylketonuria. New Engl.J.Med. 270: 810 (1964).
58. Snyderman, S.E.: In: J.A. Anderson: Proc. of Conf. on Treatment of Phenylketonuria and Allied Metabolic Diseases, Washington, DC, April 1966. U.S. Dept. Health, Education and Welfare 1967 (U.S. Government Printing Office).

59. SNyderman, S. E. and Holt, L.E., Jr.: The phenylalanine requirement of normal infants. J. Nutr. 56: 253 (1955).

60. Sтосн, M.B. and Smythe, P.M.: Does undernutrition during infancy inhibit brain growth and subsequent intellectual development? Arch.Dis. Childh. 38: 546 (1963).

61. Sutherland, B.S.; Umbarger, B. and Berry, H.K.: The treatment of phenylketonuria. A decade of results. Amer.J. Dis. Child. 111: 505 (1966).

62. Terr, A.I.; Allen, R. and Vanselow, N.A.: Immunologic responsiveness in phenylketonuria. J.amer. med. Ass. 198: 1185 (1966).

63. Treatment of Phenylketonuria. Report to the Medical Research Council of the Conference on Phenylketonuria. Brit.med.J. i: 1691 (1963).

64. Udenfriend, S: and Cooper, J.R.: Chemical estimation of tyrosine and tyramine. J. biol. Ghem. 196: 227 (1952).

65. Udenfriend, S. and Cooper, J.R.: Assay of Lphenylalanine as phenylethylamine after enzymatic decarboxylation; application to isotopic studies. J. biol. Ghem. 203: 953 (1953).

66. WhTteHEAD, R.G.: Biochemical tests in differential diagnosis of protein and calorie deficiencies. Arch. Dis. Childh. 42: 479 (1967).

67. Wrinick, M.: Malnutrition and brain development. J.Pediat. 74: 667 (1969).

68. Winick, M. and Rossa, P.: The effect of severe early malnutrition on cellular growth of the human brain. Pediat. Res. 3: 181 (1969).

69. A.E. Ames \& Company, Elkhardt, IN.

70. Informed consent was obtained for all subjects in this study.

71. Mead Johnson and Company, Evansville, IN.

72. Presented in part at the Society for Pediatric Research, Atlantic City, New Jersey, May 3, 1968. Abstract appeared in Pediatric Research 2: 426 (1968).

73. Requests for reprints should be addressed to: W.B.Hanley, M.D., The Hospital for Sick Children, 555 University Avenue, Toronto 101, Ontario, Canada.

74. Accepted for publication December 10, 1969. 